\title{
The William Farrar Site (41TT1) in the Sulphur River Basin,Titus County, Texas
}

Timothy K. Perttula

Follow this and additional works at: https://scholarworks.sfasu.edu/ita

Part of the American Material Culture Commons, Archaeological Anthropology Commons, Environmental Studies Commons, Other American Studies Commons, Other Arts and Humanities Commons, Other History of Art, Architecture, and Archaeology Commons, and the United States History Commons

Tell us how this article helped you.

This Article is brought to you for free and open access by the Center for Regional Heritage Research at SFA ScholarWorks. It has been accepted for inclusion in Index of Texas Archaeology: Open Access Gray Literature from the Lone Star State by an authorized editor of SFA ScholarWorks. For more information, please contact cdsscholarworks@sfasu.edu. 


\section{The William Farrar Site (41TT1) in the Sulphur River Basin,Titus County, Texas Creative Commons License \\ (c) $($ i) (8)}

This work is licensed under a Creative Commons Attribution-NonCommercial 4.0 International License 


\title{
The William Farrar Site (41TT1) in the Sulphur River Basin, Titus County, Texas
}

\author{
Timothy K. Perttula
}

\section{Introduction}

The William Farrar site (41TT1) is an ancestral Caddo settlement and cemetery on an alluvial terrace of the Sulphur River (Figure 1) in the East Texas Post Oak Savannah, a few miles downstream from the W. A. Ford site (41TT2) (see Goldschmidt 1935; Perttula 2016). University of Texas (UT) archaeologists completed excavations at the site in August 1934, but they had known about the site since as early as 1932, when they purchased or had donated several Caddo vessels from a Henry William Martin and, in 1934, purchased a vessel from a John Bowman, who had previously dug at the site.

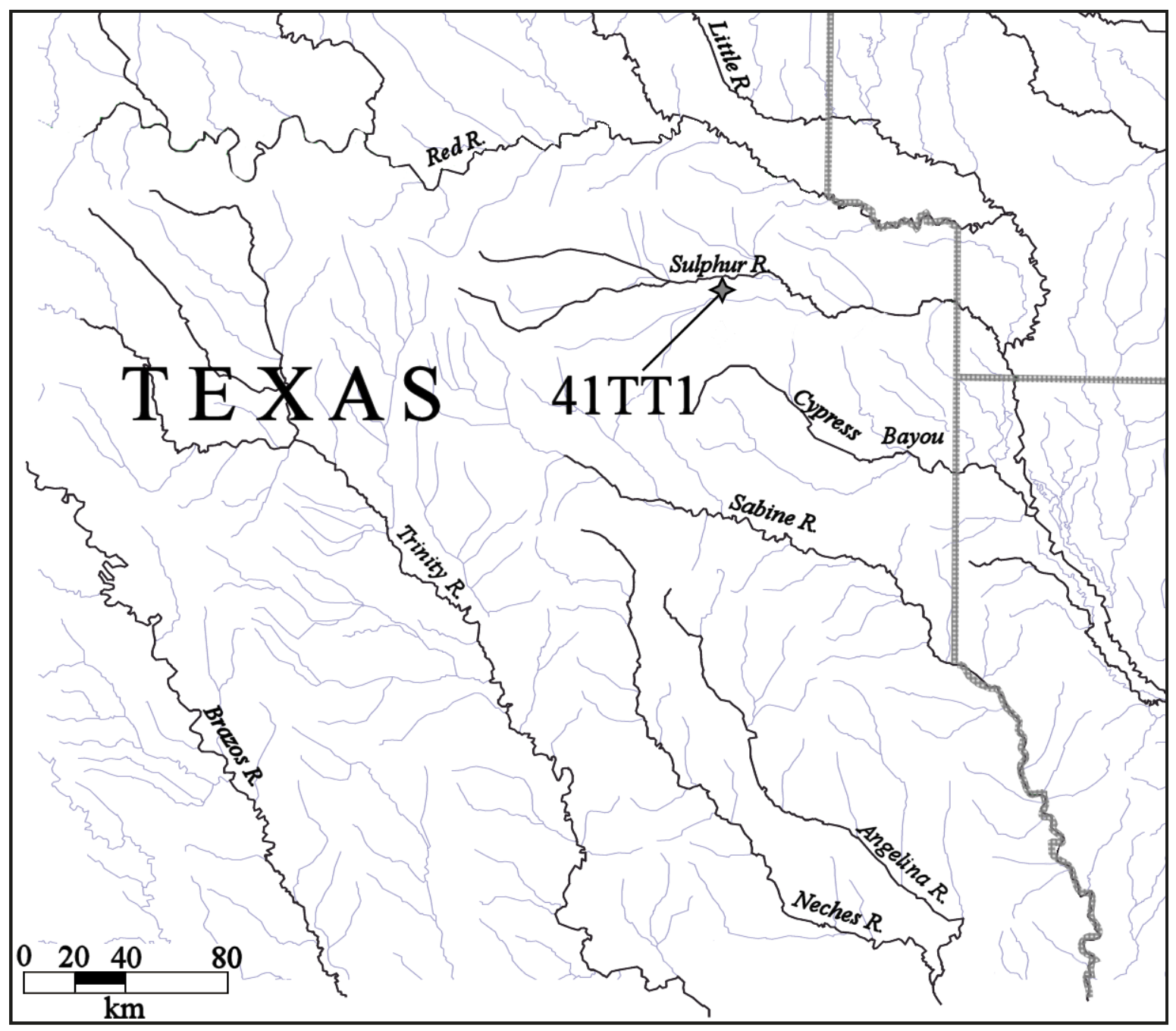

Figure 1. Location of the William Farrar site (41TT1) in East Texas. 
As will be discussed below, the work at the site disclosed that there were extensive midden deposits on the terrace, and that there were aboriginal burial features $(n=7+)$ in these midden deposits. Four of the burial features excavated by UT are from a Woodland period use of the site (ca. 500 B.C. to A.D. 800), and the remaining three burials are from its use by ancestral Caddo peoples.

\section{Excavations at the William Farrar Site}

The UT excavations at the William Farrar site were in three different areas or loci (A-C) on and near the crest of the alluvial terrace (Figure 2). Each of these areas had midden deposits, with the densest midden deposits in Locus A and B (Goldschmidt 1934:19). Locus A was set between a cellar and Mr. Martin's house, and next to an area ca. 6.6 x $3 \mathrm{~m}$ in size where Mr. Martin had previously excavated and had encountered the human remains from one burial. UT archaeologists excavated two burial features $(\mathrm{V}-2$ and $\mathrm{V}-4)$ in this locus.

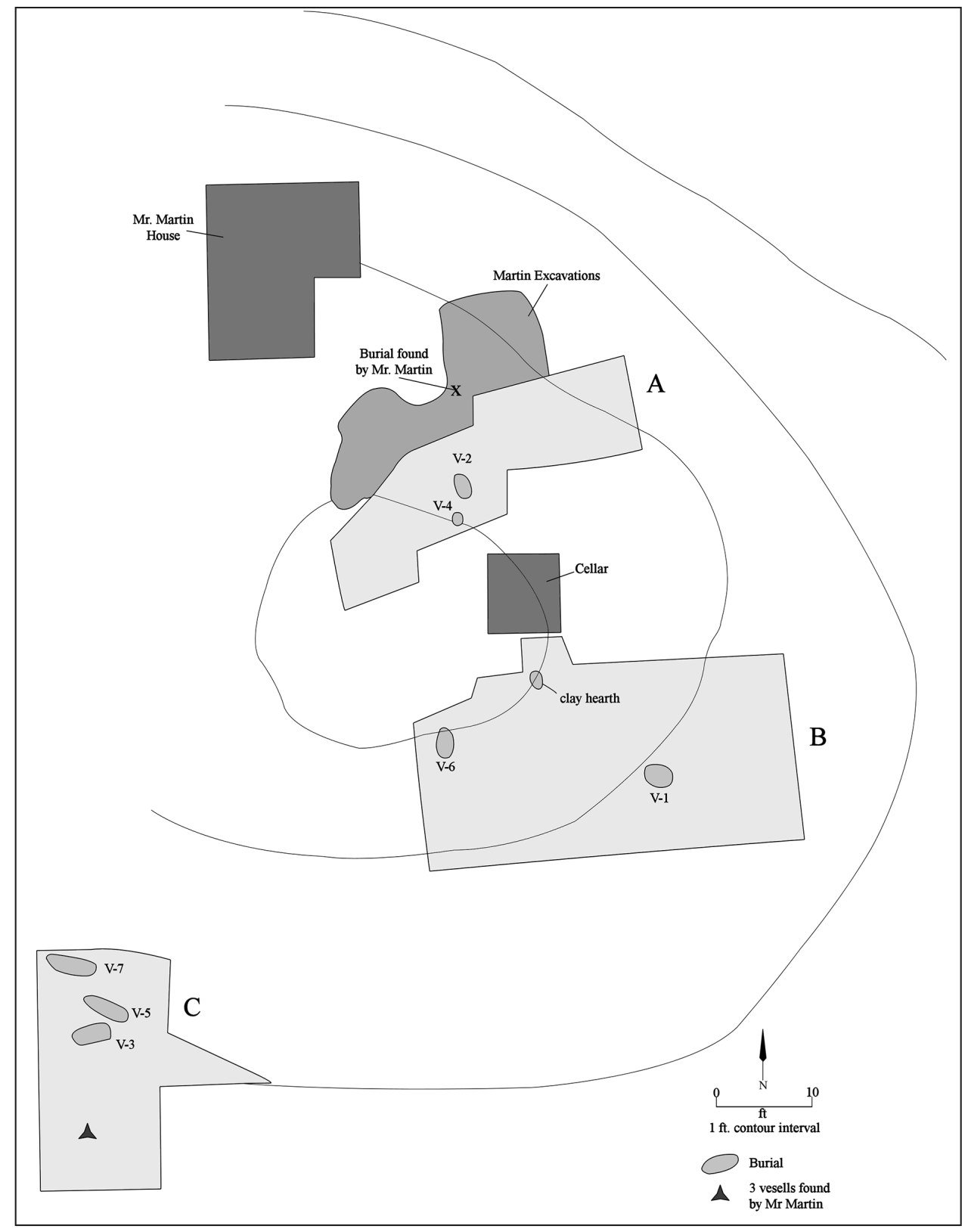

Figure 2. Plan of UT 1934 excavations at the William Farrar site (41TT1). 
Locus B was south of the cellar and was ca. 12 x 6 m in size (see Figure 2); Goldschmidt (1934) described the area as having a heavy midden deposit. Excavations here uncovered two burial features (V-1 and V-6) and a burned clay feature that may be the remnants of a hearth. Goldschmidt (1934:19) described it as "a small deposit of burnt clay. It was of a reddish color, and was evidently formed by a fire burnt on top the ground. The red color is probably due to the baking effects of the fire."

In Locus C, ca. 8.5 m west-southwest of Locus B, Mr. Martin had earlier uncovered three ceramic vessels from a burial feature. UT excavations were ca. $4.3 \times 7.3 \mathrm{~m}$ in area, and three burial features were excavated in this locus (see Figure 2).

\section{Burial Features}

The first of the burial features excavated by UT archaeologists was in Locus B (see Figure 2). It was a flexed burial of an adult oriented almost north-south and ca. $0.9 \times 0.6 \mathrm{~m}$ in size (Figure 3). The skull, long bones, and vertebral column were preserved. The burial was found at a depth of less than $30 \mathrm{~cm}$ in midden deposits, and there were no associated funerary offerings.

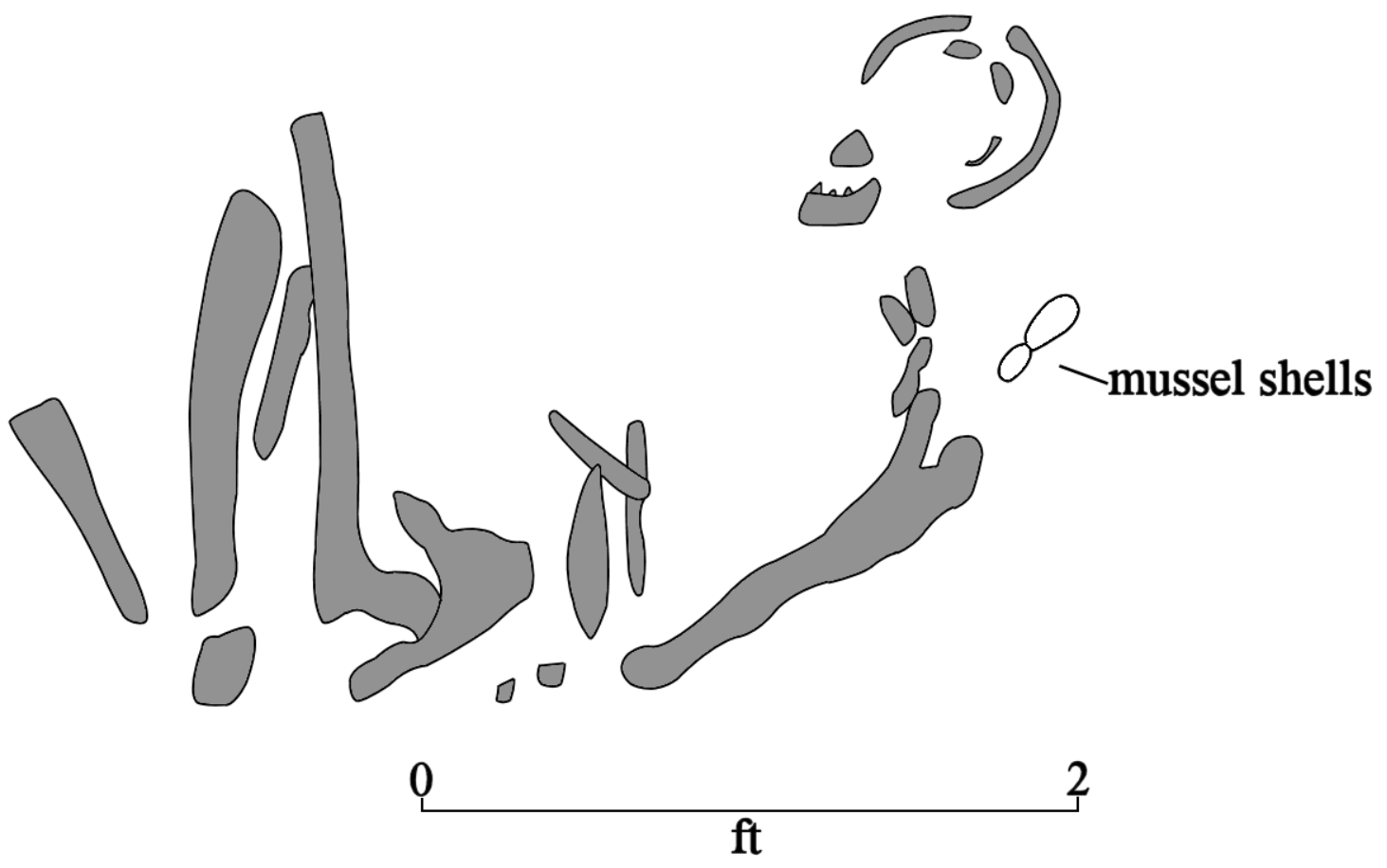

Figure 3. Plan of Burial V-1 at the William Farrar site (41TT1).

Burial V-2 was in Locus A, also in midden deposits. Human remains (skull and long bone fragments) were described by Goldschmidt (1934:8) as "badly broken up and jumbled together, so that direction nor condition of burial could be ascertained." This may have been a bundle burial, and the feature covered a $0.6 \times 0.46 \mathrm{~m}$ area. There were no associated funerary offerings.

Burial V-3 was the first of three extended supine burials excavated in Locus C (see Figure 2). All three burials were in midden deposits. Burial V-3 was oriented roughly north-south, with the head of the deceased (marked by several teeth) at the northern end of the grave, facing south (Figure 4). The grave was ca. $1.37 \times 0.51 \mathrm{~m}$ in length and width, and less than $30 \mathrm{~cm}$ bs in depth. Other preserved human remains included arm and leg bones as well as the vertebral column and pelvis. There were no associated funerary offerings with Burial V-3. 


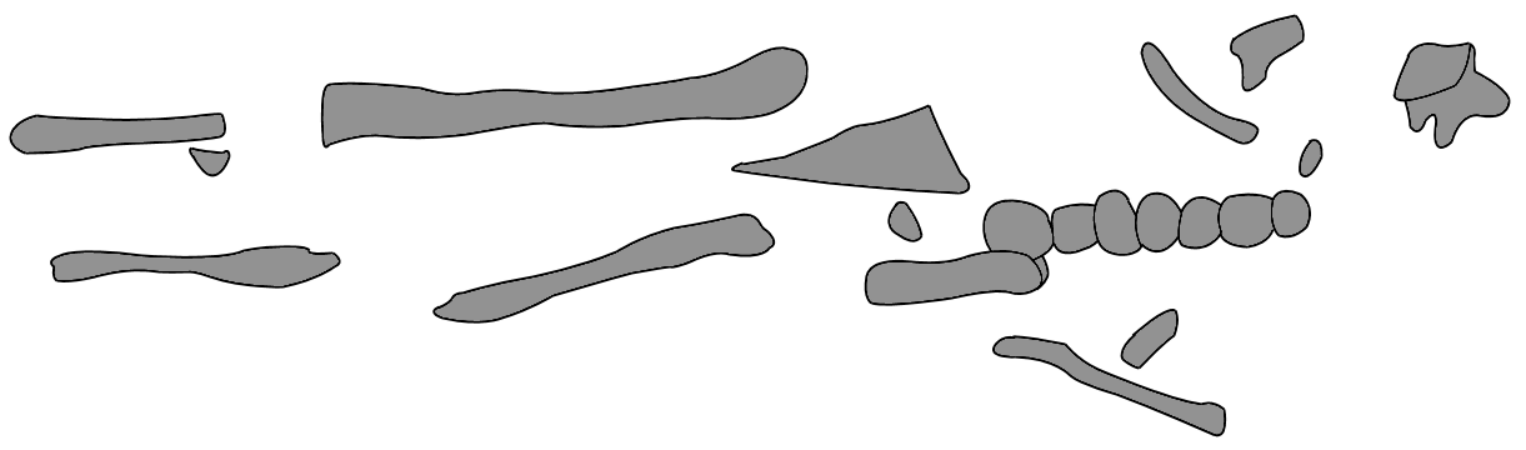

Figure 4. Plan of Burial V-3 at the William Farrar site (41TT1).

Like Burial V-2, Burial V-4 consisted of a jumbled pile of human remains, including vertebrae, ribs, and deciduous teeth, suggesting it is the burial of a child. It was ca. $60 \mathrm{~cm}$ south of Burial V-2 (see Figure 2). The burial was uncovered less than $30 \mathrm{~cm}$ bs in Locus A midden deposits, and the deceased had no associated funerary offerings.

Burial V-5 was the second extended supine burial feature in Locus C, just north of Burial V-3 (see Figure 2); it was oriented northwest-southeast, and was ca. $1.67 \mathrm{~m}$ in length; its width was not determined. The few preserved human remains included deciduous teeth and skull fragments. The grave was ca. $30 \mathrm{~cm}$ in depth, in midden deposits, and a single ceramic vessel (or the base and lower body section, see below) had been placed in the grave, ca. $46 \mathrm{~cm}$ bs, near the western side of the skull.

Burial V-6 was the second flexed burial excavated at the William Farrar site, also in Locus B (see Figure 2). Human remains preserved in the burial included the skull, arm and leg bones, ribs, and the vertebral column (Figure 5). The feature was ca. $71 \times 46 \mathrm{~cm}$ in length and width, and it was ca. $30 \mathrm{~cm}$ bs. Two Gary dart points were recovered during the excavation of Burial V-6, although Goldschmidt (1934:14; see also Goldschmidt 1935:Plate 11:1-2) did not establish if these were funerary offerings or had derived from the midden deposits.

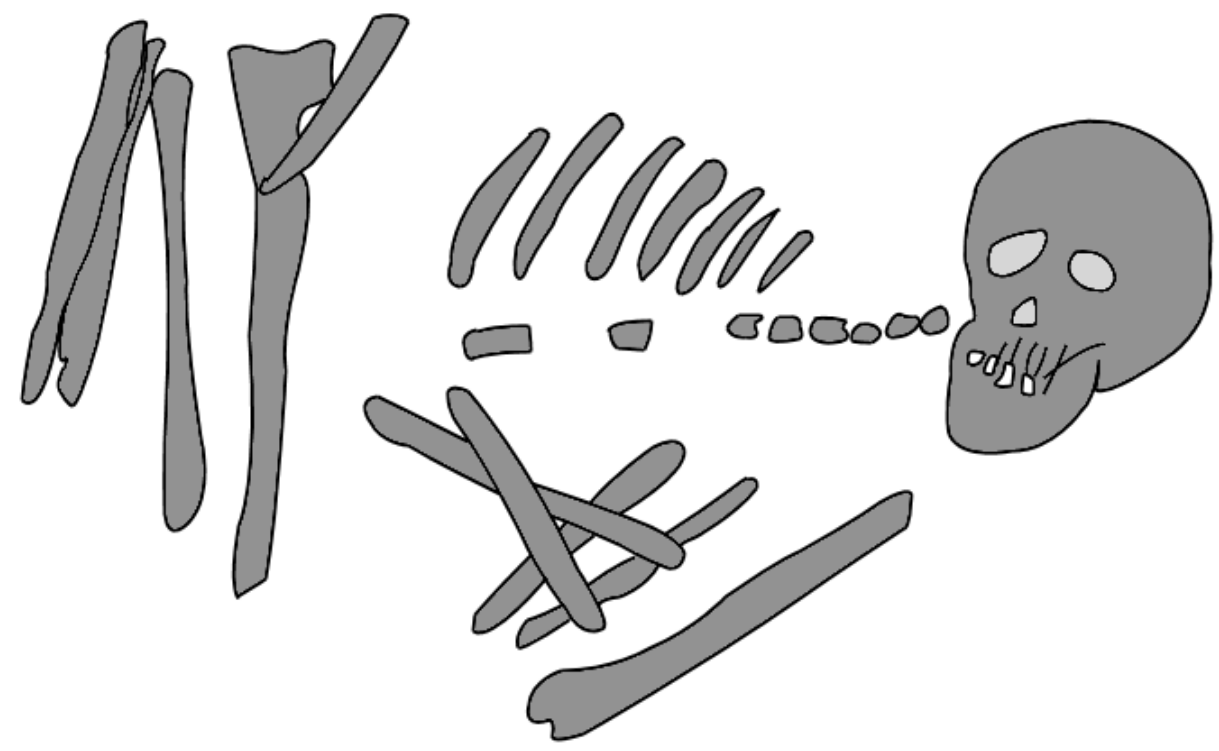

Figure 5. Plan of Burial V-6 at the William Farrar site (41TT1). 
The last of the extended supine burials in Locus C is Burial V-7. It was ca. $0.6 \mathrm{~m}$ west-southwest from Burial V-5, and was oriented roughly north-south (see Figure 2), with the head of the deceased at the northern end of the grave. Human remains were relatively well preserved, and included the skull, vertebral column and ribs, arm and leg bones, and the pelvis (Figure 6). The grave was ca. $1.63 \times 0.36 \mathrm{~m}$ in length and width, and rested at ca. $30 \mathrm{~cm}$ bs. Three ceramic vessels were placed as funerary offerings with the burial, one vessel by the east side of the head, and two others placed between the lower legs (Figure 6).

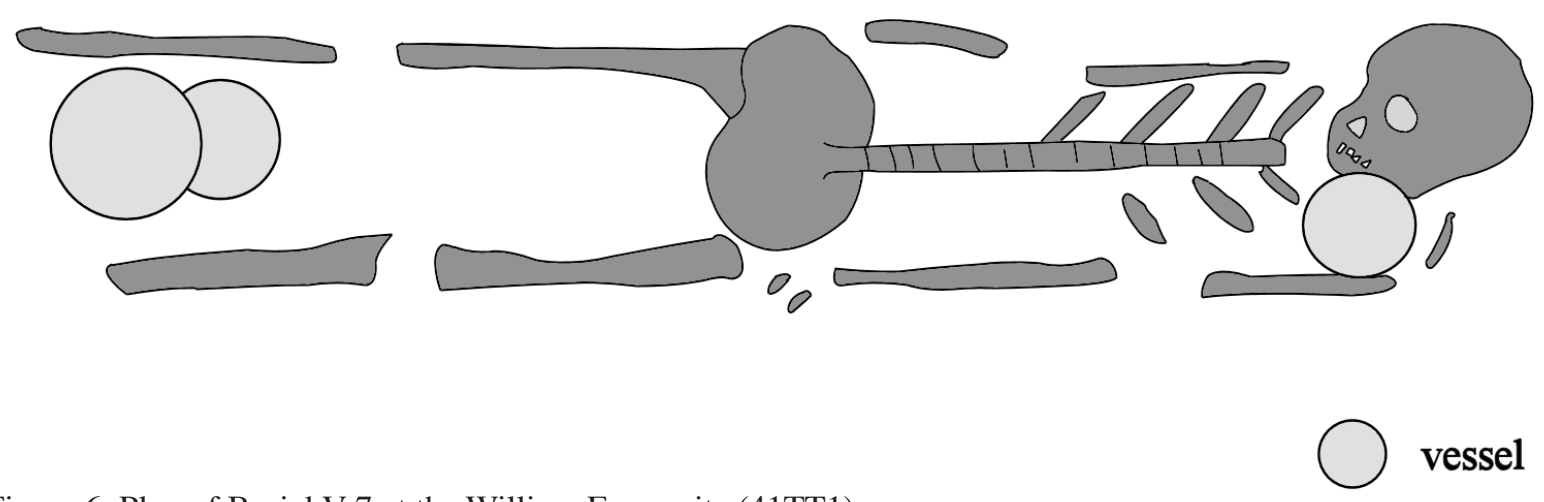

Figure 6. Plan of Burial V-7 at the William Farrar site (41TT1).

\section{Ceramic Vessels}

There are twelve ceramic vessels, or sections thereof, in the TARL collections from the William Farrar site. Three of the vessels were purchased by The University of Texas from H. W. Martin in August 1932; four other vessels were donated by H. W. Martin in 1932; one vessel was purchased from John Bowman in August 1934; and the remaining four vessels were funerary offerings in Burial V-5 and Burial V-7 in Area C. The Martin vessels are from burial features in Area A (see Figure 2).

SITE NAME OR SITE NUMBER: William Farrar (41TT1)

VESSEL NO.: 2, Purchased in August 1932 from H. W. Martin

VESSEL FORM: Jar with rim peaks

NON-PLASTICS AND PASTE: grog

RIM AND LIP FORM: Everted rim and rounded lip

CORE COLOR: B (fired and cooled in a reducing or low oxygen environment)

INTERIOR SURFACE COLOR: very dark gray

EXTERIOR SURFACE COLOR: very dark gray

WALL THICKNESS (IN MM): rim, $6.1 \mathrm{~mm}$

INTERIOR SURFACE TREATMENT: none

EXTERIOR SURFACE TREATMENT: smoothed on the body

HEIGHT (IN CM): 9.8

ORIFICE DIAMETER (IN CM): 9.6 
DIAMETER AT BOTTOM OF RIM OR NECK (IN CM): 7.9

BASE DIAMETER (IN CM) AND SHAPE OF

BASE: $4.5 \mathrm{~cm}$, circular and flat

ESTIMATED VOLUME (IN LITERS): 0.6

DECORATION (INCLUDING MOTIF AND

ELEMENTS WHEN APPARENT): The rim has two rows of fingernail punctations that are separated by four sets of curvilinear and vertical appliqued ridges on the rim peak and upper rim (Figure 7). The upper body has four sets of curvilinear and vertical appliqued ridges, with two rows of fingernail punctations within the area demarcated by the curvilinear appliqued ridges.

PIGMENT USE AND LOCATION ON VESSEL: none

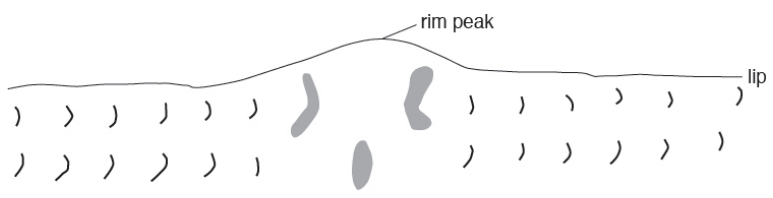

TYPE AND VARIETY (IF KNOWN): Unidentified utility ware

SITE NAME OR SITE NUMBER: William Farrar

VESSEL NO.: 3, Purchased in August 1932

VESSEL FORM: Short-rimmed jar

NON-PLASTICS AND PASTE: shell

RIM AND LIP FORM: Direct rim and rounded lip

CORE COLOR: B (fired and cooled in a low oxygen or reducing environment)

INTERIOR SURFACE COLOR: dark gray

EXTERIOR SURFACE COLOR: dark gray

WALL THICKNESS (IN MM): rim, $3.5 \mathrm{~mm}$

INTERIOR SURFACE TREATMENT: none

EXTERIOR SURFACE TREATMENT: smoothed

HEIGHT (IN CM): 9.1

ORIFICE DIAMETER (IN CM): 4.4

DIAMETER AT BOTTOM OF RIM OR NECK (IN CM): 5.6 
BASE DIAMETER (IN CM) AND SHAPE OF BASE: $4.8 \mathrm{~cm}$, circular and flat

ESTIMATED VOLUME (IN LITERS): 0.2

DECORATION (INCLUDING MOTIF AND ELEMENTS WHEN APPARENT): Plain

PIGMENT USE AND LOCATION ON VESSEL: none

TYPE AND VARIETY (IF KNOWN): Unidentified plain ware

SITE NAME OR SITE NUMBER: William Farrar

VESSEL NO.: 4, Purchased August 1932

VESSEL FORM: Jar with four rim peaks

NON-PLASTICS AND PASTE: shell

RIM AND LIP FORM: Everted rim and rounded lip

CORE COLOR: B (fired and cooled in a low oxygen or reducing environment)

INTERIOR SURFACE COLOR: very dark gray

EXTERIOR SURFACE COLOR: very dark gray; fire clouds on the body

WALL THICKNESS (IN MM): rim, $5.4 \mathrm{~mm}$

INTERIOR SURFACE TREATMENT: smoothed

EXTERIOR SURFACE TREATMENT: smoothed on the body

HEIGHT (IN CM): 14.7

ORIFICE DIAMETER (IN CM): 12.3

DIAMETER AT BOTTOM OF RIM OR NECK (IN CM): 12.2

BASE DIAMETER (IN CM) AND SHAPE OF BASE: $7.7 \mathrm{~cm}$, circular and flat

ESTIMATED VOLUME (IN LITERS): 1.1

DECORATION (INCLUDING MOTIF AND ELEMENTS WHEN APPARENT): The rim has four sets of two vertically oriented appliqued nodes under each rim peak, as well as a row of tool punctations at the rim-body juncture. The vessel body has four vertical appliqued fillets - centered beneath the rim peaks - that extend halfway down the vessel body.

PIGMENT USE AND LOCATION ON VESSEL: none

TYPE AND VARIETY (IF KNOWN): Unidentified utility ware 
SITE NAME OR SITE NUMBER: William Farrar

VESSEL NO.: 15, Donated by H. W. Martin

VESSEL FORM: Carinated bowl

NON-PLASTICS AND PASTE: shell

RIM AND LIP FORM: Inverted rim and rounded lip

CORE COLOR: B (fired and cooled in a low oxygen or reducing environment)

INTERIOR SURFACE COLOR: dark gray

EXTERIOR SURFACE COLOR: dark gray

WALL THICKNESS (IN MM): rim, $4.8 \mathrm{~mm}$

INTERIOR SURFACE TREATMENT: smoothed

EXTERIOR SURFACE TREATMENT: burnished

HEIGHT (IN CM): 6.9

ORIFICE DIAMETER (IN CM): 14.2

DIAMETER AT BOTTOM OF RIM OR NECK (IN CM): 16.8

BASE DIAMETER (IN CM) AND SHAPE OF BASE: $5.4 \mathrm{~cm}$, circular and rounded

ESTIMATED VOLUME (IN LITERS): 0.6

DECORATION (INCLUDING MOTIF AND ELEMENTS WHEN APPARENT): The rim panel is divided into six sections by sets of six vertical to curvilinear engraved lines. Within each section is a single curvilinear scroll line with one hooked arm (Figure 8).

PIGMENT USE AND LOCATION ON VESSEL: none

TYPE AND VARIETY (IF KNOWN): Simms Engraved

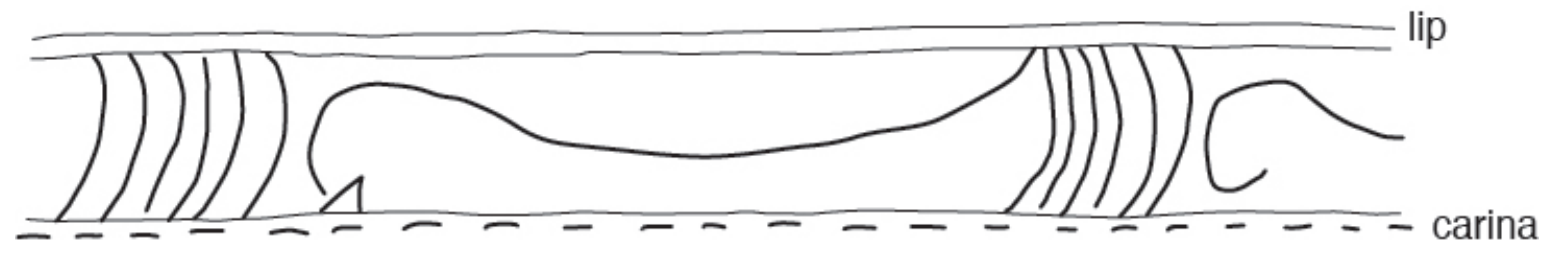

Figure 8. Simms Engraved carinated bowl decorative elements from the William Farrar site, Donated by H. W. Martin. 
SITE NAME OR SITE NUMBER: William Farrar

VESSEL NO.: 16, Donated by H. W. Martin

VESSEL FORM: Jar with four rim peaks

NON-PLASTICS AND PASTE: grog

RIM AND LIP FORM: Direct rim and rounded lip

CORE COLOR: B (fired and cooled in a reducing or low oxygen environment)

INTERIOR SURFACE COLOR: dark gray

EXTERIOR SURFACE COLOR: dark gray; fire clouds on the body

WALL THICKNESS (IN MM): rim, $6.5 \mathrm{~mm}$

INTERIOR SURFACE TREATMENT: smoothed

EXTERIOR SURFACE TREATMENT: smoothed on the body

HEIGHT (IN CM): 9.5

ORIFICE DIAMETER (IN CM): 8.3

DIAMETER AT BOTTOM OF RIM OR NECK (IN CM): 8.4

BASE DIAMETER (IN CM) AND SHAPE OF BASE: $5.9 \mathrm{~cm}$, circular and flat

ESTIMATED VOLUME (IN LITERS): 0.5

DECORATION (INCLUDING MOTIF AND ELEMENTS WHEN APPARENT): The rim has two horizontal neck banded rows and a vertical appliqued ridge under each rim peak. There is a single row of linear tool punctations at the rimbody juncture and four sets of either vertical or triangular-shaped linear tool punctated elements. The vertical linear tool punctations occur as sets of either three (one time), four (two times), or seven (one time) vertical lines that extend from just below the rim-body juncture to near the vessel base. The triangular-shaped zones of linear tool punctations are filled with either horizontal or vertical tool punctations (Figure 9).

PIGMENT USE AND LOCATION ON VESSEL: none

TYPE AND VARIETY (IF KNOWN): cf. La Rue Neck Banded

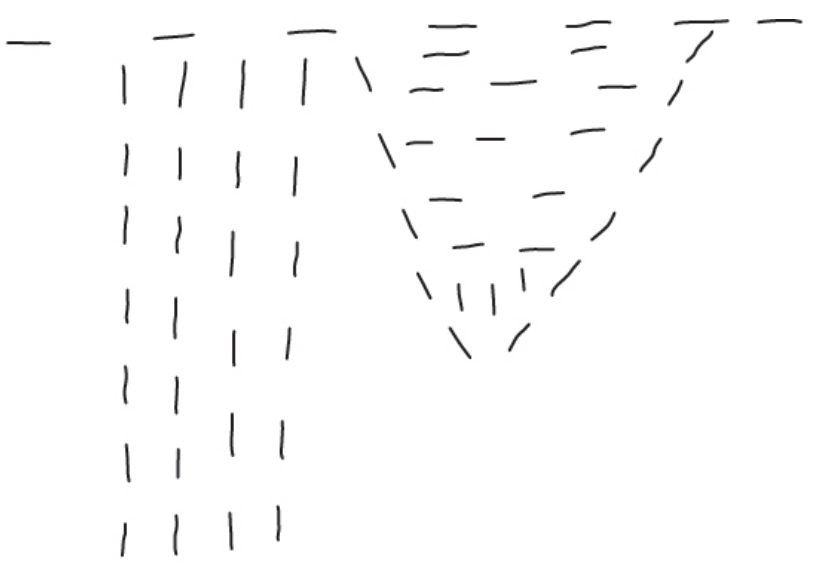

Figure 9. cf. La Rue Neck Banded jar decorative elements from the William Farrar site (41TT1), donated by H. W. Martin. 
SITE NAME OR SITE NUMBER: William Farrar

VESSEL NO.: 17, Donated by H. W. Martin

VESSEL FORM: Jar

NON-PLASTICS AND PASTE: grog

RIM AND LIP FORM: Everted rim and rounded lip

CORE COLOR: $\mathrm{F}$ (fired in a reducing environment and cooled in the open air)

INTERIOR SURFACE COLOR: brown; fire clouds on the body

EXTERIOR SURFACE COLOR: brown; fire clouds on the body

WALL THICKNESS (IN MM): rim, $7.7 \mathrm{~mm}$

INTERIOR SURFACE TREATMENT: smoothed

EXTERIOR SURFACE TREATMENT: smoothed on the body

HEIGHT (IN CM): 17.0

ORIFICE DIAMETER (IN CM): 14.6

DIAMETER AT BOTTOM OF RIM OR NECK (IN CM): 14.0

BASE DIAMETER (IN CM) AND SHAPE OF BASE: $5.6 \mathrm{~cm}$, circular and rounded

ESTIMATED VOLUME (IN LITERS): 2.2

DECORATION (INCLUDING MOTIF AND ELEMENTS WHEN APPARENT): The rim has four sets of two vertical appliqued nodes, as well as two rows of tool punctations, and a single horizontal incised line at the rim-body juncture. There are four vertical appliqued ridges on the vessel body that have been placed beneath the appliqued nodes on the rim. There are also two widely-spaced tool punctated rows on the vessel body, one row near the rim-body juncture and the other mid-body.

PIGMENT USE AND LOCATION ON VESSEL: none

TYPE AND VARIETY (IF KNOWN): Unidentified utility ware

SITE NAME OR SITE NUMBER: William Farrar

VESSEL NO.: 18, Donated by H. W. Martin

VESSEL FORM: Jar

NON-PLASTICS AND PASTE: shell

RIM AND LIP FORM: Everted rim and rounded lip 
CORE COLOR: B (fired and cooled in a reducing or low oxygen environment)

INTERIOR SURFACE COLOR: dark grayish-brown

EXTERIOR SURFACE COLOR: dark gray

WALL THICKNESS (IN MM): rim, $5.9 \mathrm{~mm}$

INTERIOR SURFACE TREATMENT: none

EXTERIOR SURFACE TREATMENT: none

HEIGHT (IN CM): 12.7

ORIFICE DIAMETER (IN CM): 12.8

DIAMETER AT BOTTOM OF RIM OR NECK (IN CM): 11.0

BASE DIAMETER (IN CM) AND SHAPE OF BASE: $7.0 \mathrm{~cm}$, circular and flat

ESTIMATED VOLUME (IN LITERS): 1.0

DECORATION (INCLUDING MOTIF AND ELEMENTS WHEN APPARENT): There are horizontal brushing marks on the vessel body.

PIGMENT USE AND LOCATION ON VESSEL: none

TYPE AND VARIETY (IF KNOWN): Unidentified utility ware

SITE NAME OR SITE NUMBER: William Farrar

VESSEL NO.: 1, Purchased in August 1934 from John Bowman

VESSEL FORM: Carinated bowl

NON-PLASTICS AND PASTE: grog

RIM AND LIP FORM: Direct rim, and rounded, exterior folded lip

CORE COLOR: B (fired and cooled in a reducing or low oxygen environment)

INTERIOR SURFACE COLOR: dark gray

EXTERIOR SURFACE COLOR: dark gray

WALL THICKNESS (IN MM): rim, $7.0 \mathrm{~mm}$

INTERIOR SURFACE TREATMENT: smoothed

EXTERIOR SURFACE TREATMENT: burnished

HEIGHT (IN CM): 7.4 
ORIFICE DIAMETER (IN CM): 17.6

DIAMETER AT BOTTOM OF RIM OR NECK (IN CM): 17.2

BASE DIAMETER (IN CM) AND SHAPE OF BASE: $5.7 \mathrm{~mm}$, circular and flat

ESTIMATED VOLUME (IN LITERS): 0.8

DECORATION (INCLUDING MOTIF AND ELEMENTS WHEN APPARENT): There are four repeating sets of a slanted scroll and semi-circle motif on the rim panel (Figure 10). The semi-circles are defined by two opposed sets of two curvilinear engraved lines. The upper and lower scroll fill zones have excised brackets, narrow columns, and triangular areas (Figure 10)

PIGMENT USE AND LOCATION ON VESSEL: none

TYPE AND VARIETY (IF KNOWN): Ripley Engraved, var. Caldwell (see Perttula 2005)

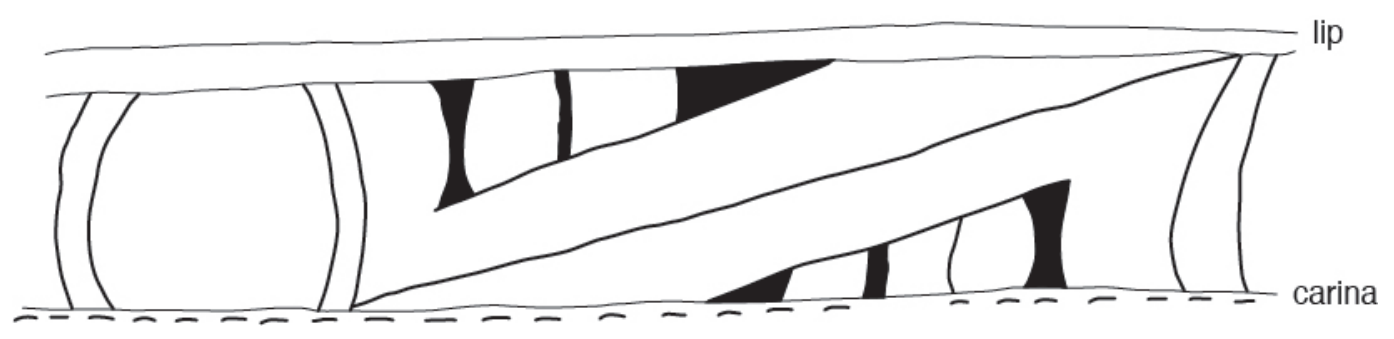

Figure 10. Ripley Engraved, var. Caldwell carinated bowl decorative elements in the William Farrar site (41TT1) collection.

SITE NAME OR SITE NUMBER: William Farrar

VESSEL NO.: Burial V-5

VESSEL FORM: Small bowl or jar

NON-PLASTICS AND PASTE: grog

RIM AND LIP FORM: N/A

CORE COLOR: F (fired in a reducing environment and cooled in the open air)

INTERIOR SURFACE COLOR: brown

EXTERIOR SURFACE COLOR: brown

WALL THICKNESS (IN MM): body, $5.1 \mathrm{~mm}$; base, $5.4 \mathrm{~mm}$

INTERIOR SURFACE TREATMENT: none

EXTERIOR SURFACE TREATMENT: smoothed

HEIGHT (IN CM): N/A 
ORIFICE DIAMETER (IN CM): N/A

DIAMETER AT BOTTOM OF RIM OR NECK (IN CM): N/A

BASE DIAMETER (IN CM) AND SHAPE OF BASE: N/A; flat base

ESTIMATED VOLUME (IN LITERS): N/A

DECORATION (INCLUDING MOTIF AND ELEMENTS WHEN APPARENT): Plain, but vessel only represented by a body-base sherd.

PIGMENT USE AND LOCATION ON VESSEL: none

TYPE AND VARIETY (IF KNOWN): Unidentified plain ware

SITE NAME OR SITE NUMBER: William Farrar

VESSEL NO.: 32, Burial V-7

VESSEL FORM: Bowl

NON-PLASTICS AND PASTE: grog

RIM AND LIP FORM: Direct rim and rounded lip

CORE COLOR: $\mathrm{F}$ (fired in a reducing environment and cooled in the open air)

INTERIOR SURFACE COLOR: dark reddish-brown

EXTERIOR SURFACE COLOR: brown

WALL THICKNESS (IN MM): rim, $4.2 \mathrm{~mm}$

INTERIOR SURFACE TREATMENT: smoothed

EXTERIOR SURFACE TREATMENT: burnished

HEIGHT (IN CM): 6.9

ORIFICE DIAMETER (IN CM): 13.4

DIAMETER AT BOTTOM OF RIM OR NECK (IN CM): N/A

BASE DIAMETER (IN CM) AND SHAPE OF BASE: $7.5 \mathrm{~cm}$, circular and flat

ESTIMATED VOLUME (IN LITERS): 0.4 
DECORATION (INCLUDING MOTIF AND ELEMENTS WHEN APPARENT): The rim of the vessel has four sets of two vertical and horizontal scroll lines on either side of a broad excised vertical engraved line and upper and lower horizontal zones with negative ovals (Figure 11). The negative ovals - four to each upper and lower zone-are defined by a series of excised bracket elements.

PIGMENT USE AND LOCATION ON VESSEL: engraved

TYPE AND VARIETY (IF KNOWN): Unidentified fine ware

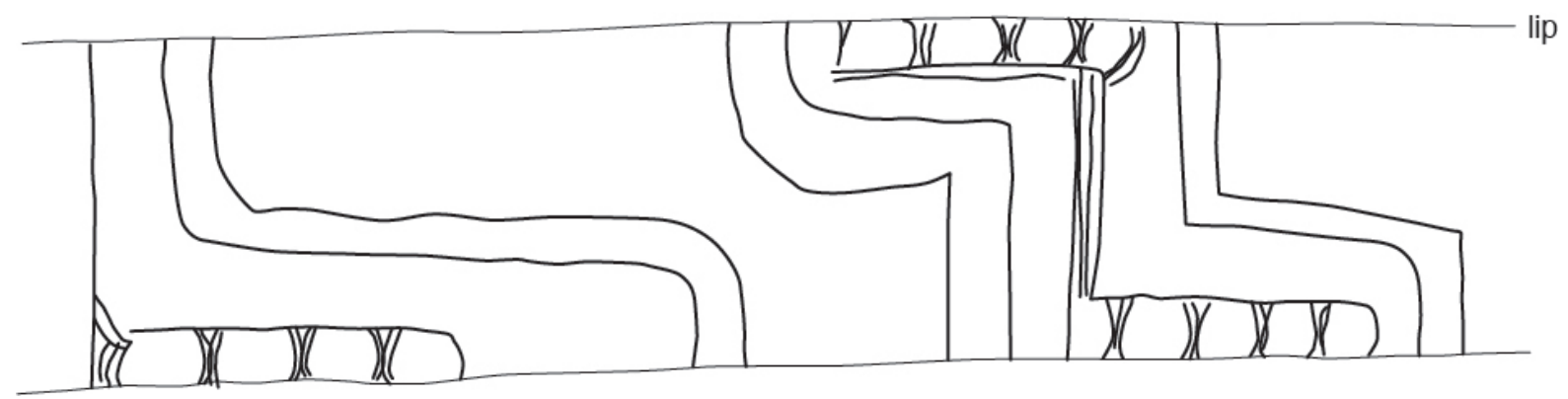

Figure 11. Decorative elements on Bowl (No. 32) from Burial V-7 at the William Farrar site (41TT1).

SITE NAME OR SITE NUMBER: William Farrar

VESSEL NO.: 33, Burial V-7

VESSEL FORM: Jar with a short neck

NON-PLASTICS AND PASTE: shell

RIM AND LIP FORM: Direct rim and rounded lip

CORE COLOR: B (fired and cooled in a reducing or low oxygen environment)

INTERIOR SURFACE COLOR: very dark gray

EXTERIOR SURFACE COLOR: dark gray; fire clouds on the rim and body

WALL THICKNESS (IN MM): rim, $6.3 \mathrm{~mm}$

INTERIOR SURFACE TREATMENT: none

EXTERIOR SURFACE TREATMENT: smoothed on the body

HEIGHT (IN CM): 10.3

ORIFICE DIAMETER (IN CM): 6.2

DIAMETER AT BOTTOM OF RIM OR NECK (IN CM): 8.3

BASE DIAMETER (IN CM) AND SHAPE OF BASE: $4.4 \mathrm{~cm}$, circular and rounded

ESTIMATED VOLUME (IN LITERS): 0.5 


\section{DECORATION (INCLUDING MOTIF AND ELEMENTS WHEN APPARENT): Plain}

PIGMENT USE AND LOCATION ON VESSEL: none

TYPE AND VARIETY (IF KNOWN): Unidentified plain ware

SITE NAME OR SITE NUMBER: William Farrar

VESSEL NO.: 34, Burial V-7

VESSEL FORM: Jar with four rim peaks

NON-PLASTICS AND PASTE: grog

RIM AND LIP FORM: Everted rim and rounded lip

CORE COLOR: G (fired in a reducing or low oxygen environment and cooled in the open air)

INTERIOR SURFACE COLOR: very dark gray

EXTERIOR SURFACE COLOR: brown; fire clouds on the rim, body, and base

WALL THICKNESS (IN MM): rim, $6.7 \mathrm{~mm}$

INTERIOR SURFACE TREATMENT: smoothed

EXTERIOR SURFACE TREATMENT: none

HEIGHT (IN CM): 14.5

ORIFICE DIAMETER (IN CM): 14.6

DIAMETER AT BOTTOM OF RIM OR NECK (IN CM): 14.0

BASE DIAMETER (IN CM) AND SHAPE OF BASE: $7.6 \mathrm{~cm}$, circular and flat

ESTIMATED VOLUME (IN LITERS): 1.3

\section{DECORATION (INCLUDING MOTIF AND} ELEMENTS WHEN APPARENT): The rim and body have four sets of upper and lower incised rectangles, and four central incised rectangles, filled with small circular tool punctations (Figure 12). The incised lines forming two sides of the central incised rectangles are cross-hatched.

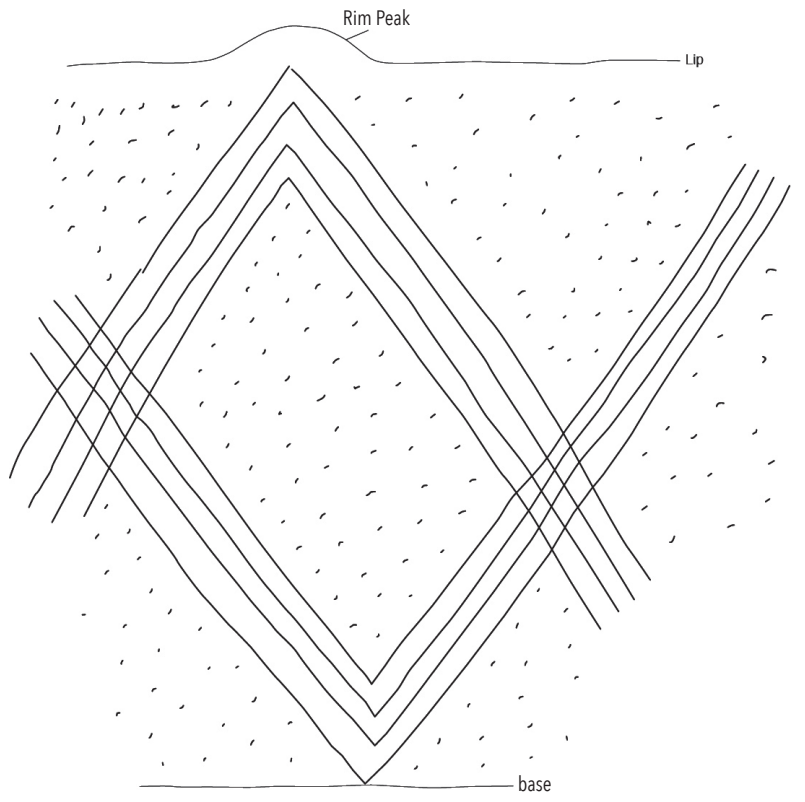

Figure 12. Incised-punctated jar (No. 34) decorative elements from Burial V-7 at the William Farrar site (41TT1).

PIGMENT USE AND LOCATION ON VESSEL: none

TYPE AND VARIETY (IF KNOWN): Unidentified utility ware 


\section{Ceramic Vessel Sherds}

The 436 ceramic vessel sherds in the UT collections from the William Farrar site are from vessels tempered primarily with grog ( 83.5 percent), followed by grog-bone-temper ( 8.0 percent), shell temper ( 6.9 percent), bone (1.4 percent), and grog-hematite ( 0.2 percent) (Table 1$)$. In the utility wares, 90 percent are from grog-tempered vessels, compared to only 69 percent of the fine wares. Almost 27 percent of the fine wares in the assemblage are from shell-tempered vessels-compared to only 5.6 percent of the plain ware and only 1.4 percent of the utility wares that are from shell-tempered vessels. The shell-tempered vessel sherds are likely to have originated as vessels made by Late Caddo McCurtain phase potters living to the north on the Red River (see Perttula et al. 2012).

Table 1. Ceramic wares and temper groups in the ceramic vessel sherds from the disturbed burial at the William Farrar site (41TT1).

\begin{tabular}{lllllll}
\hline Ware & & \multicolumn{5}{c}{ Temper Categories } \\
& Grog & Grog-Bone & Grog-Hematite & Bone & Shell & N \\
& & & & & & \\
\hline Plain & 272 & 28 & 1 & 5 & 18 & 324 \\
Utility & 63 & 6 & - & - & 1 & 70 \\
Fine & 29 & 1 & - & 6 & 30 & 436 \\
\hline Totals & 364 & 35 & 1 & & & \\
\hline
\end{tabular}

The 112 decorated sherds in the William Farrar site ceramic assemblage includes both utility ware (62.5 percent) and fine wares (37.5 percent) (Table 2); 10.7 percent of the decorated sherds are from shell-tempered vessels (see Table 1). Sherds with incised (30 percent of the utility wares) and punctated (22.9 percent) decorative elements are well represented in the assemblage, including body sherds with parallel incised lines, diagonal opposed incised lines (probably from a Canton Incised vessel) (Figure 13a), cross-hatched lines (also from Canton Incised vessels), horizontal and diagonal opposed incised lines (Figure 13c), horizontal and zigzag incised lines (Figure 13b), and rim and body sherds with rows of tool punctations.

Table 2. Decorative methods and elements in the utility ware and fine ware sherds from the William Farrar site (41TT1).

\begin{tabular}{llll}
\hline Decorative method and elements & Rim & Body & $N$ \\
\hline
\end{tabular}

\section{Utility ware}

\section{Appliqued}

appliqued nodes

parallel appliqued ridge

straight appliqued ridge

$\begin{array}{lll}- & 2 & 2 \\ - & 1 & 1 \\ - & 7 & 7\end{array}$

\section{Brushed}

opposed brushed marks overlapping brushed marks parallel brushed marks vertical brushed marks

$\begin{array}{lll}- & 1 & 1 \\ - & 1 & 1 \\ - & 9 & 9 \\ 1 & 1 & 2\end{array}$


Table 2. Decorative methods and elements in the utility ware and fine ware sherds from the William Farrar site (41TT1), cont.

\begin{tabular}{llll}
\hline Decorative method and elements & Rim & Body & N \\
\hline $\begin{array}{l}\text { Brushed-Incised } \\
\text { parallel brushed-incised marks and lines }\end{array}$ & - & 8 & 8 \\
$\begin{array}{l}\text { Incised } \\
\text { cross-hatched incised lines }\end{array}$ & & & 2 \\
diagonal incised lines & 1 & 1 & 1 \\
diagonal opposed incised lines & 1 & - & 1 \\
horizontal incised lines & - & 1 & 2 \\
horizontal and diagonal opposed incised lines & 2 & - & 1 \\
horizontal and zigzag incised lines & - & 1 & 1 \\
parallel incised lines & - & 1 & 1 \\
straight incised line & - & 11 & 1 \\
vertical incised lines & - & 1 & 1 \\
$\begin{array}{l}\text { Incised-Appliqued } \\
\text { straight incised line-straight appliqued ridge }\end{array}$ & - & 1 & \\
Neck Banded & & & 1 \\
neck banded rows & - & 1 & 1 \\
$\begin{array}{l}\text { Punctated } \\
\text { fingernail punctated rows } \\
\text { diagonal tool punctated rows } \\
\text { tool punctated rows }\end{array}$ & & & 1
\end{tabular}

\section{Fine ware}

\section{Engraved}

cross-hatched engraved zone curvilinear engraved lines curvilinear-straight engraved lines curvilinear hatched zone-negative oval curvilinear hatched zone-negative oval-diagonal lines diagonal engraved lines, int. surface diagonal opposed engraved lines hatched triangle el. horizontal engraved lines horizontal engraved lines-vertical lug handle horizontal-curvilinear engraved lines horizontal and curvilinear engraved lines and curvilinear cross-hatched zone horizontal-diagonal engraved lines horizontal engraved lines-diagonal hatched zones horizontal-vertical engraved lines horizontal engraved line-vertical hatched triangle el. parallel engraved lines slanted scroll line-vertical hatched zone straight engraved line triangle el.

$\begin{array}{lll}- & 1 & 1 \\ - & 2 & 2 \\ - & 1 & 1 \\ - & 1 & 1 \\ - & 1 & 1 \\ 1 & - & 1 \\ 1 & 1 & 2 \\ - & 1 & 1 \\ 6^{* *} & - & 6 \\ 1^{*} & - & 1 \\ 1 & 1^{*} & 2 \\ - & 1 & 1 \\ & & \\ 1 & 1 & 2 \\ 1 & - & 1 \\ - & 1 & 2 \\ 2 & - & 4 \\ - & 4 * & 1 \\ - & 1 & 1 \\ - & 1 & -\end{array}$


Table 2. Decorative methods and elements in the utility ware and fine ware sherds from the William Farrar site (41TT1), cont.

\begin{tabular}{|c|c|c|c|}
\hline Decorative method and elements & Rim & Body & $\mathrm{N}$ \\
\hline $\begin{array}{l}\text { Engraved-Punctated } \\
\text { vertical-diagonal engraved lines-upper zone of linear } \\
\text { punctations }\end{array}$ & 1 & - & 1 \\
\hline $\begin{array}{l}\text { Red-slipped } \\
\text { int. red-slipped } \\
\text { int./ext. red-slipped }\end{array}$ & $\begin{array}{l}- \\
-\end{array}$ & $\begin{array}{l}1 \\
7 * *\end{array}$ & $\begin{array}{l}1 \\
7\end{array}$ \\
\hline Totals & 27 & 85 & 112 \\
\hline
\end{tabular}

*includes one shell-tempered sherd

**includes four shell-tempered sherds

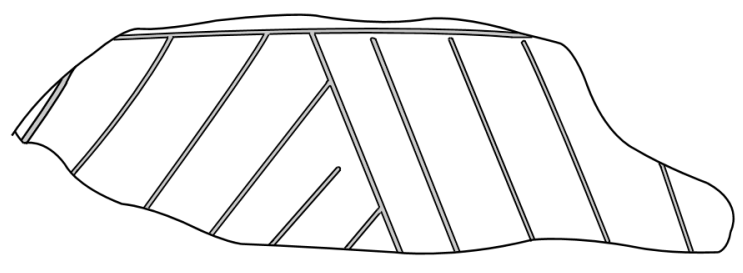

a

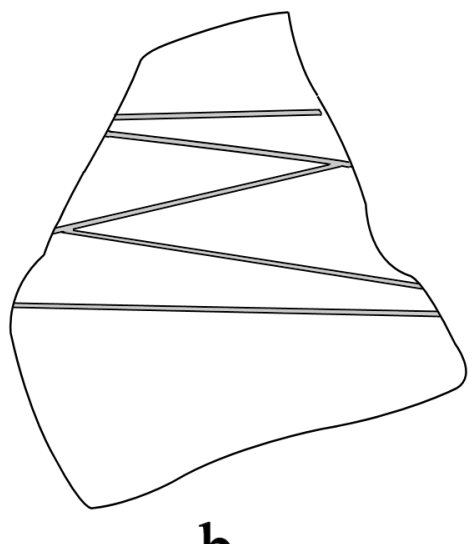

b

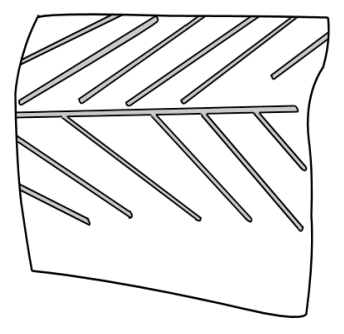

C

Figure 13. Selected utility ware decorative elements in the William Farrar ceramic assemblage.

Sherds with appliqued ridges and nodes comprise 14.3 percent of the utility wares from the site (see Table 2), and sherds with brushed (18.6 percent) and brushed-incised (11.4 percent) decorative elements comprise another 30 percent of the utility wares. One sherd has a straight appliqued ridge adjacent to a single straight incised line. The only shell-tempered sherd in the utility wares from the William Farrar site is a Nash Neck Banded body sherd (see Suhm and Jelks 1962:Plate 56).

The fine ware sherds in the William Farrar site assemblage include those from engraved (78.6 percent), engraved-punctated (2.4 percent), and red-slipped (19.0 percent) vessels. About 26 percent of the fine ware sherds are from shell-tempered vessels. 
The grog, grog-bone, and bone-tempered fine ware sherds $(n=30)$ include sherds from engraved carinated bowls $(n=26)$ and red-slipped vessels $(n=4)$. Rims and upper rim sherds have diagonal (Sanders Engraved), diagonal lines on the vessel interior (Sanders Engraved), diagonal opposed (Sanders Engraved), horizontal, horizontal-curvilinear, horizontal-diagonal engraved lines (Figure 14b), horizontal engraved lines and diagonal hatched zones, diagonal engraved lines, a negative oval, a curvilinear hatched zone (Figure 14g), horizontal engraved lines and vertical hatched triangles (Figure 14c-d), and triangle elements (see Table 2). Other sherds have horizontal and curvilinear engraved lines and a curvilinear cross-hatched zone (Figure 14a), and one sherd has a slanted scroll line and a vertical hatched zone.

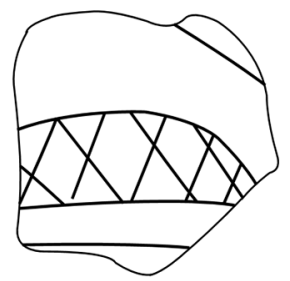

a

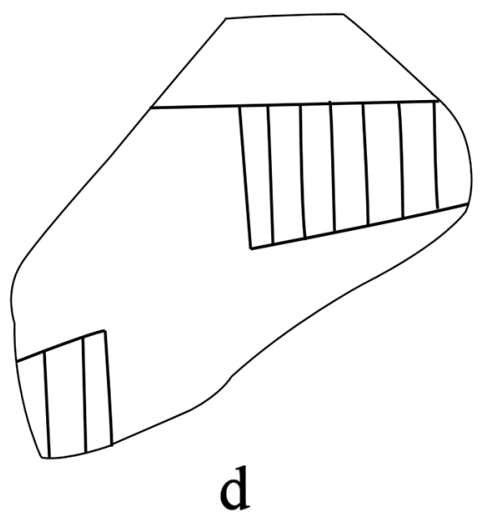

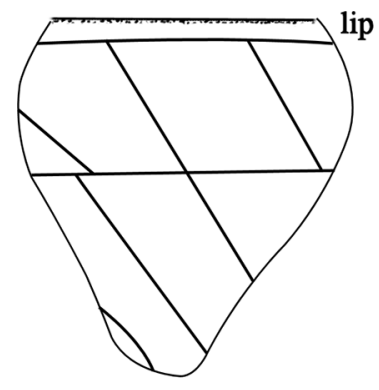

b
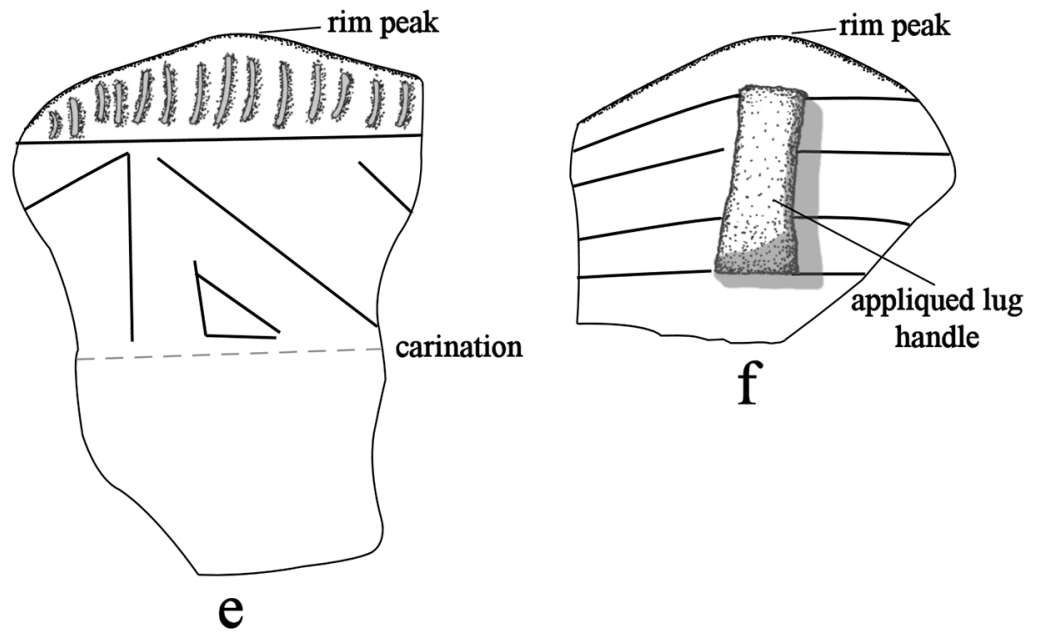
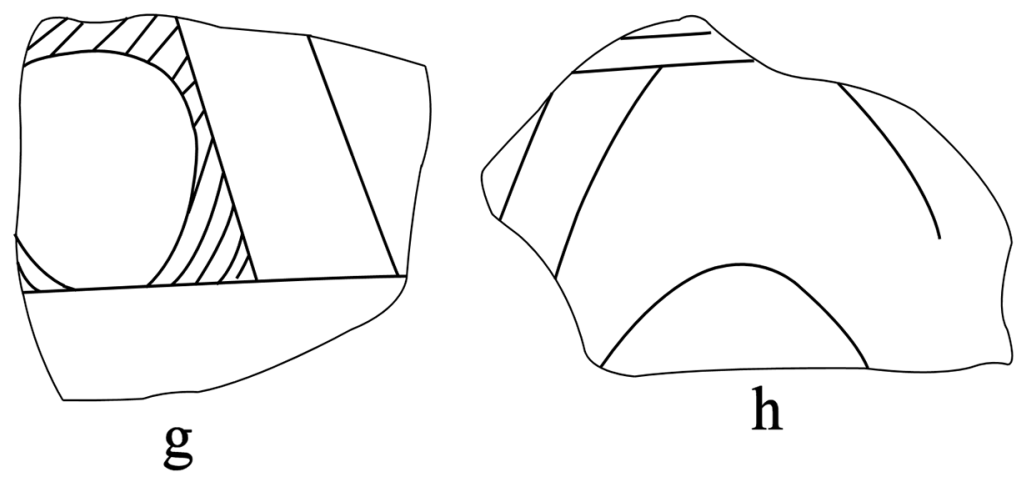

Figure 14. Selected fine ware decorative elements on sherds from the William Farrar site: a-d, g, grog-tempered engraved; e, engraved-punctated; $\mathrm{f}, \mathrm{h}$, shell-tempered engraved sherds. 
The one engraved-punctated sherd is a grog-tempered rim sherd from a Ripley Engraved, var. Walkers Creek carinated bowl (see Figure 14e; see also Perttula 2005:322 and Figure A-91). The rim panel has part of a nested triangle element (likely in association with an engraved circle element), as well as a smaller separate triangle element. Above the engraved motif on the thickened rim and rim peak are a series of regularly spaced linear and vertical punctations.

The shell-tempered fine wares include seven engraved rim and body sherds and four red-slipped body sherds (see Table 2). Four of the shell-tempered rim sherds have only horizontal engraved lines (see Table 2), while another rim is from a rim peaked vessel with horizontal engraved lines and a vertical lug handle (see Figure 14f). An engraved body sherd has parallel engraved lines, and another, likely from an Avery Engraved vessel (see Suhm and Jelks 1962:Plate 3), has horizontal and curvilinear engraved lines (see Figure 14h). The red-slipped sherds may be from Clement Redware vessels (see Flynn 1976) or are the slipped but non-engraved sherds from shell-tempered fine ware engraved vessels.

\section{Summary and Conclusions}

The William Farrar site (41TT1) on the Sulphur River in the East Texas Post Oak Savannah is an ancestral Woodland and ancestral Caddo settlement and small cemetery investigated by both local collectors (prior to 1932) and by University of Texas archaeologists in 1934. The Woodland period occupation is best marked by four flexed and bundle burials in two different areas, as well as midden deposits in several areas on the landform, but the only artifacts that may be associated with these features are Gary dart points; no clear Woodland period ceramic vessels or vessel sherds are present in the assemblage from the William Farrar site.

The ancestral Caddo use of the William Farrar site took place both before and after ca. A.D. 1400, and it is suspected, based on the analysis of the decorated sherds (primarily from grog-tempered vessels) recovered from the midden excavations, that the continued accumulation of the midden deposits here occurred primarily before A.D. 1400, likely in the Middle Caddo period (ca. A.D. 1200-1400). The Middle Caddo period occupation includes three extended burials excavated by UT archaeologists, and funerary offerings with these burials include the body and base of a small bowl or jar, an incisedpunctated jar in Burial V-7 that compares favorably to Canton Incised (see Perttula 2016:Figure 18), a distinctive engraved bowl, and a plain short-necked jar.

Other burial features at the William Farrar site were excavated by H. W. Martin and John Bowman in Area A (see Figure 2), and the post-A.D. 1400 vessels found in these burials (purchased or donated) include both grog-tempered $(n=4)$ as well as shell-tempered vessels $(n=4)$. The shell-tempered vessels were likely not manufactured locally (see Selden et al. 2014), but were apparently manufactured by McCurtain phase Caddo potters living on the middle reaches of the Red River to the north of the William Farrar site, and traded or exchanged with a local Sulphur River Caddo population affiliated with the Titus phase. The grog-tempered vessels in this component include a Ripley Engraved, var. Caldwell carinated bowl, a La Rue Neck Banded jar, and two appliqued-punctated jars. The shell-tempered vessels in the Late Caddo period component include a plain short-necked jar, a punctated-appliqued jar with rim peaks, a jar with a brushed body and a plain rim, and a cf. Simms Engraved carinated bowl. The occurrence of a cf. Simms Engraved vessel in one burial feature at the site suggests that the cemetery here was in use until at least ca. A.D. 1550.

\section{Acknowledgments}

Thanks to Lauren Bussiere of the Texas Archeological Research Laboratory at The University of Texas for access to the collections from the William Farrar site (41TT1). Lance Trask prepared the figures for this article. 


\section{References Cited}

Flynn, P.

1976 A Study of Red-Filmed Pottery from the Clement Site (Mc-8), McCurtain County, Oklahoma. Bulletin of the Oklahoma Anthropological Society 25:127-134.

Goldschmidt, W. R.

1934 Field Notes on the Partial Excavation of a Burial Site on the Farrar Brothers' Farm, Titus County, Texas. MS on file, Texas Archeological Research Laboratory, The University of Texas at Austin.

1935 A Report on the Archeology of Titus County in East Texas. Bulletin of the Texas Archeological and Paleontological Society 7:89-99.

Perttula, T. K.

2005 Vessel Descriptions from Burial Features. In Archeological Investigations at the Pilgrim's Pride Site (41CP304), a Titus Phase Community in the Big Cypress Creek Basin, Camp County, Texas, Volume II, edited by T. K. Perttula, pp. 159-414. Report of Investigations No. 30. Archeological \& Environmental Consultants, LLC, Austin and Pittsburg.

2016 The W. A. Ford Site (41TT2), Titus County, Texas. Journal of Northeast Texas Archaeology 60:1-52.

Perttula, T. K., M. B. Trubitt, and J. S. Girard

2012 The Use of Shell-Tempered Pottery in the Caddo Area of the Southeastern United States. Southeastern Archaeology 30(2):242-267.

Selden, R. Z., Jr., T. K. Perttula, and D. L. Carlson

2014 INAA and the Provenance of Shell-Tempered Sherds in the Ancestral Caddo Region. Journal of Archaeological Science 47:113-120.

Suhm, D. A. and E. B. Jelks (editors)

1962 Handbook of Texas Archeology: Type Descriptions. Special Publication No. 1, Texas Archeological Society, and Bulletin No. 4, Texas Memorial Museum, Austin. 